\title{
一対比較のための非計量的手法
}

\author{
小林、涁*・芝田勉**
}

\section{A Nonmetrical Method for Paired Comparisons}

\author{
Akira Kobayashi* and Tsutomu Shibata**
}

In this paper, the authors propose a new nonmetrical algorithm to construct an interval scale from the numerical data obtained by paired comparisons. In the algorithm, the band function model is introduced, and, with respect to the function's average characteristics, a monotone increasing relation is assumed between the numerical data and the difference of a psychological scale on the attribute of the compared objects.

The algorithm to construct an interval scale is based on an iterative method of calculus, and has the following advantages.

1) Not necessarily all results about the comparison of each pair of objects are required.

2) The amount of fazziness or scattering included in the results of the paired comparisons can be known from the width of the dead zone introduced in the algorithm.

3) An interval scale can be constructed more precisely by this algorithm than by a usual paired comparison method.

Through the numerical experiments using artificial data, the fundamental characteristics of the algorithm are examined.

For testing its practical utility, a case of subjective comparisons of weights by human hands is taken up as, an example, and the algorithm is applied to reconstructing their real weights. The reconstructed weights show good agreement with the real weights measured by a direct balance.

\section{1. まえがき}

本論文は，比較判断の結果得られたデータに対する 計量化処理法に関し，間隔尺度構成を目的として非計

†第 19 回自動制御連合講演会で発表（昭 $51 \cdot 11$ )

* 東京工業大学工学部 東京都目黒区大岡山 2-12-1

**オリンパス光学工業(株) 八王子市石川町 2951

* Faculty of Engineering, Tokyo Institute of Technology, Meguro-ku, Tokyo

** Olympus Optical Co. Ltd., Hachiooji

(Received May 31, 1977)
量的な新しい手法を提案するるすのである.

官能検查などに見られるように計測量概念が未だ整 っていない対象の計量化に゙おいては心理学的測定法が 活用されるが，中でも一対比較法は質の良い結果が得 られるむのとされよく用いられている11。このような 計測行為の初期的段階に扔いて得られる測定值は結果 として心理学的尺度にすぎないが，物理的尺度による 計測量概念の整備を図っていくことを考えると，ての 心理学的尺度を尺度論的 ${ }^{2)}$ にできるだけ整備しておく ことが望ましく，少なくとも間隔尺度を構成しておく と都合がよい：すなわち因子分析法3)や回帰分析法な ど多変量解析法 ${ }^{4)}$ の手法に拈いては，基本的に間隔尺 度をなす尺度間の関連分析について種々の手法がすで に用意されているので，それらの手法を活用していく てとが効果的であるからである。またそのような間隔 尺度が物理的尺度に直接的に結びついていく場合す十 分考えられる。

一対比較法に抢ける代表的な手法として Thurstone の方法, Scheffé の方法などがあり, 比較判断の結果 はそれぞれ順位を表す数值や評点の形で与えられる12. ての場合その数值処理にあたっては，判断に付随した あいまいさやばらつきは加法的確率変数として扱わ れ，さらにそのあいまいさやばらつきが減少し零にな った極限では一対比較判断の結果は, 各対象について の心理学的尺度の差に比例した数值を与えるむのとさ れている ${ }^{5), 6)}$. つまり一対比較判断の平均的性格は間 隔尺度をなすむのであることが始めから仮定されてい るととになる。し加し人間感覚の非線形性（たとえば Weber-Fechner の法則など）を考慮すれば，てのよ うな仮定は必ずしも現実的でなく，むう少しゆるい条 件を前提とする手法が必要になる.

本研究では以上の観点から, 帯関数モデルを考え, 一対比較判断の結果はある範囲にわたってい゙らつきを あつものであるがその平均的性格は心理学的尺度の差 と単調増加関係にある数值が得られるすのと仮定し， そのような数值の組から心理学的尺度につき間隔尺度 
を与えるためのアルゴリズムを考察する.

アルゴリズムは非計量多次元尺度構成の数值処理法 に見られる考え方 ${ }^{7299}$ を応用した逐次的手法で計算機 による処理を前提とするが，(1)すべての比較対に対 する判断結果を必ずしす必要としない，(2)判断結果 に入っているあいまいさやばらつきの程度を，アルゴ リズムに導入されている不感带幅の大きさから知るて とができる，(3)従来の一対比較法の数值処理より質 の良い間隔尺度を構成することができる，などの利点 を有している. 以下ではそれらの利点を人工データに 対する数值実験を通じて検討すると共に，重さの主観 的比較結果から実際の質量を再現する実験に適用しア ルゴリズムの実用上の有効さを検証する.

\section{2. 問題の記述}

本論文では，N個の対象を考えその可能な対に関し ていわゆる一対比較判断を行うむのとする．乙の場合 各対象 $x_{i}$ に対応して仮想的に考えた心理学的尺度を $m_{i}$ とし， $x_{i}$ に対する $x_{j}$ の比較判断の結果を数值 的に $\varphi\left(x_{i}, x_{j}\right)$ で表す. 乙のとき, $\varphi\left(x_{i}, x_{j}\right)$ と $m_{i}$, $m_{j}$ の間にはつぎの関係があるむのと考える.

$$
\begin{aligned}
& f_{u}\left(m_{j}-m_{i}\right) \geqq \varphi_{i j} \equiv \varphi\left(x_{i}, x_{j}\right) \geqq f_{d}\left(m_{j}-m_{i}\right) ; \\
& \quad i, j \in\{1, \cdots, N\}
\end{aligned}
$$

ここで $f_{u}(m), f_{d}(m)$ は共に $m$ に関するある単調 増加関数である. (Fig. 1 参照).

(1)式に拈いて $f_{u}(m)$ と $f_{d}(m)$ とに狭まれる領域 は比較判断に含まれるあいまいさやばらつきの範囲を 表現し，また $f_{u}^{\prime}(m)$ と $f_{d}(m)$ が単調増加関数である てとにようて比較判断の平均的性格が $m_{j}-m_{i}$ と単 調増加関係偟あることを表現する. 以下てれを一対比 較の帯関数モデルと乎ぶが, このモデルは Thurstone の方法や Scheffé の方法で仮定されている， $\varphi_{j i}$ の平 均的性格は $m_{j}-m_{i}$ に比例するという条件 ${ }^{5), 6)}$ を大 幅に緩めたむのであると共に, 従来一般の一対比較法 で扱われているほとんどのデータを統一的に表現する

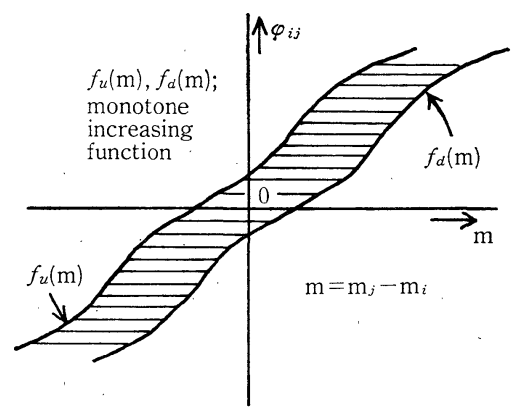

Fig. 1 Band function model for paired comparisons
あので広い活用の可能性をむつと考える.

さてわれわれの目標は適切な $m_{i}$ を最終的に決定す るととである。しかしわれわれが最初手にするデータ は $\varphi_{i j}$ だけであり $f_{u}(m)$ や $f_{d}(m)$. についてはその 単調増加性以外まったく未知である。 そのため $m_{i}$ を 決定しようとすると直接的な数理的手法でなく何か新 しい逐次的手法を考案する必要がある，そこでつぎの ような問題が生ずる.

$\Gamma N$ 個の対象につき, その一対比較判断に関する数 值の組 $\varphi_{i j}$ が与えられた場合，（1）式の前提のもとに 間隔尺度1をなすようその心理的尺度 $m_{i}$ を構成する 方法を見出すとと」

この問題に解答を与えることが本研究の主題であ る.

\section{3. 非計量的アルゴリズムの考え方}

説明をわかりやすくするために，まず(1)式におい て $f_{u}(m)$ と $f_{d}(m)$ の差が小さくなり零になった極 限を考える.すなわち判断にあいまいさやばらつきが なくなった理想的状況のもとでアルゴリズムの基本的 性格を考えるわけである，乙の場合(1)式はつぎのよ うに書ける.

$$
\begin{aligned}
& \varphi_{i j}=f\left(m_{j}-m_{i}\right) ; i, j \in\{1, \cdots N\} \\
& f(m) ; m \text { に関する単調増加関数 }
\end{aligned}
$$

$(2)$ 式を仮定すれば， $f(m)$ の関数形は未知である から $\varphi_{i j}$ から知れる情報はその数值的順序のみであ って数值自体に特別な意味はない，そこで $\varphi_{i j}$ を小 さいほうから順に並べ，その順序で各 $\varphi_{i j}$ の順位を 求めそれを $\alpha_{i j}$ とする.

一方適当に $m_{i}$ を仮定すれば

$$
d_{i j} \equiv m_{j}-m_{i}
$$

が与えられ， $d_{i j}$ 住関する同じような順位 $\beta_{i j}$ を決 めるととができる. この場合, むし $\alpha_{i j}$ と $\beta_{i j}$ がま ったく一致すれば仮定された $m_{i}$ はデータ $\varphi_{i j}$ に則 して間隔尺度を構成する正しい解の一つとなる(注 1 . しかし一般には最初から一致が得られることはまれで あり，そのため $m_{i}$ に関して適当な修正が必要とな る. この修正を行う根拠を与えるため，つぎのような $\alpha_{i j}$ と $\beta_{i j}$ の不一致の程度を表す測度 $S$ を定義し, これを順位ひずみと呼ぶ。

$$
S=\sum_{i, j=1}^{N}\left|\alpha_{i j}-\beta_{i, j}\right|\left(d_{k l}-d_{i j}\right)^{2}
$$

ただし $d_{k l}$ はその順位について $\beta_{k l}=\alpha_{i j}$ となるす

（注 1) 本論文では直接触れないが, 別の数理的解析によれ ばこの種の問題の解は一意的に決まるのではなく解が ある領域をもつととが知れる ${ }^{132}$. 
のが選ばれる．順位ひずみの定義 では, $\varphi_{i j}$ と $d_{i j}$ の順位の違いお よび $d_{i j}^{\prime}$ の大きさの違いが相乗 的に考慮され，当然 $S$ は非負であ り，また $S=0$ は $m_{i}$ につき修 正の必要がない状態にあるととを 意味する.

なお便宜上 $m_{i}$ は次式を満たす あのとするが，間隔尺度ではその 原点之単位の取り方に任意性があ るから一般性は失われない。

$$
\begin{aligned}
& \sum_{i=1}^{N} m_{i}=0 \\
& \sum_{i=1}^{N} m_{i}^{2}=1
\end{aligned}
$$

てのような $S$ を導入すると， $S$ が減少するよう $m_{i}$ の適当な修正を行えばょく，乙こでは最急降下法に従 い，つぎのような修正を繰返しつつ; 逐次 $S=0$ に収 束させるようにした.

$$
m_{i} \Rightarrow m_{i}-\gamma \frac{\partial S}{\partial m_{i}}
$$

$\gamma$ は一応, 正の定数であるが, 収束速度を加味し状 況に応じて適応性をむたせるため若干の工夫が施され ている. 以上のアルゴリズムは Kruskal の非計量多 次元尺度構成法の考え方 $\left.{ }^{8)}, 9\right)$ を応用したむのである が，(2)式で関数 $f$ の引数が距離でなく $m_{j}-m_{i}$ に なっている点, 順位を活用するる点, “順位ひずみの定義 の仕方などまったく異なったあのである.

一方，帯関数モデルに幅が存在する実際的な状況に おいては以上のアルゴリズムにつぎのような若干の工 夫を施せばよい，すなわち比較判断結果に幅を考える わけであるから， $\varphi_{i j}$ の間の小さな差は $\varphi_{i j}$ の順位を 決めるうえで決定的な意味をむちえない，そてで不感 帯を考えその幅をととすると，

$$
\left|\varphi_{i j}-\varphi_{k l}\right| \leqq \varepsilon
$$

の関係にある $\varphi_{i j}$ と $\varphi_{k l}$ についてはその差によって 両者間の順位をつけることを保留し $d_{i j}$ のほうから 決まる $\beta_{i j}$ に準じて $\alpha_{i j}$ を決める. $\varepsilon$ の值を固定し たまま $m_{i}$ の修正を行い $S$ が零に収束するかどうか 判断する. 零に収束しないときは適当な段階で $m_{i}$ の 修正を打切り, $\varepsilon$ を適当に増加させ同様の操作を行 い，Sが零に収束するまで操作を続行する．乙のよう な方法を用いると帯関数モデルに幅が存在していてす うまく $m_{i}$ を決定することができると共に，その幅の 大きさを不感帯幅との大きさとして知ることが可能と なる。

\section{4. 人エデータによる検討}

本節では数值例を示しながら前節で述べたアルゴリ ズムのもつ主要な性質について述べる.

人工データは対象の個数を 10 とし， $m_{i}$ を適当に 定めて $d_{i j}$ を求め, $d_{i j}$ の単調增加変換として $\varphi_{i j}$ を 与えたものを利用した，その場合の $m_{i}$ 抢よび $d_{i j}$ を

Table 1 亿示す. てのような $\varphi_{i j}$ から最初の $m_{i}$ が, ぞのようにまたどの程度再現できるかを検討するのが 本節の目的である. $d_{i j}$ の表で左下半分は $d_{j i}=-$ $d_{i j}$ の性質があるため省略してある。なお本節では一 貫して Table 1 の数值を用いる.

\section{1 帯関数モデルの幅が零の場合}

(i) $f$ の関数形の影響

$d_{i j}$ 加 $\varphi_{i j}$ への単調增加変換飞関して, Fig. 2 に示すような関数形を 5 種類用意し，主として $m_{i}$ の 収束の様子と再現された值の質について関数形の影響 を観察した．Fig. 3 は全体的な収束の様子を示す分 散図の一例であり, Fig. 4 は Fig. 3 のデータにつ いて特定の $d_{i j}$ を選びその収束の様子を図示したむ のである.

Fig. 2 Examples of monotone increasing function prepared

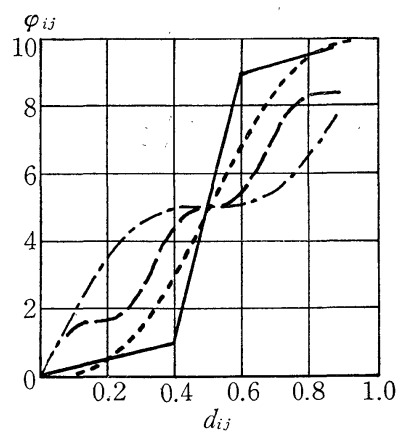



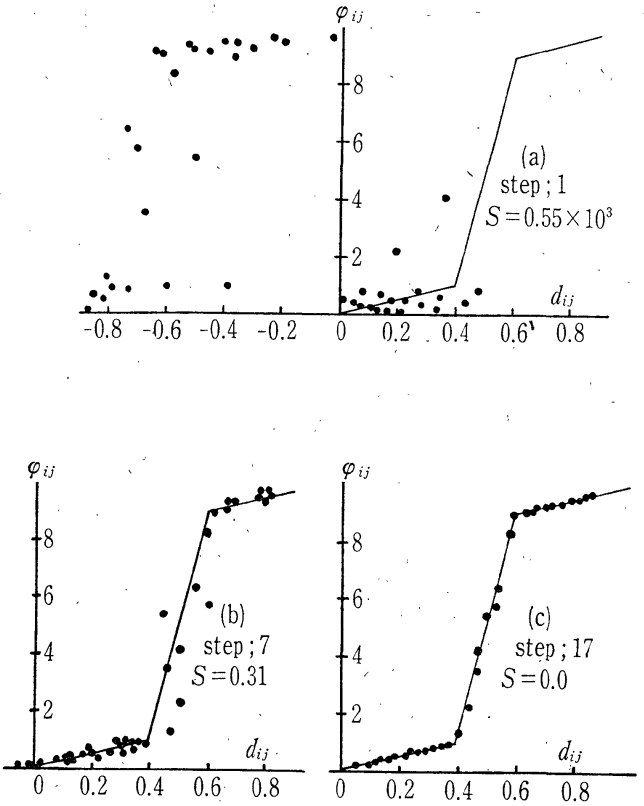

Fig. 3 Examples of scatter diagram

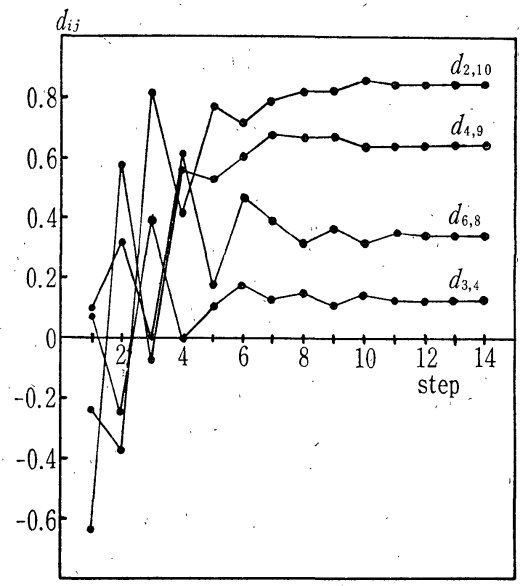

Fig. 4 An aspect of convergence

このようなデータの観察の範囲では，関数の傾きが 急な所や緩やかな所, 角張った所での違いを含め関数 形の違いによる影響として有意なむのはまったく現わ れなかった。乙れは $\varphi_{i j}$ から順位情報を得る段階で関 数形の影響を受ける部分がほとんど除去されてしまう ためであると考えられる。

(ii) 初期值の与え方

この種の問題で $m_{i}$ の初期值をどう与えるかは計算 の回数を少なくするうえで重要な鍵であるが，幾種類 かの初期值の与え方を検討した結果，次式のように初 期值 $m_{i 0}$ を与えると効果的であることが判明した.

$$
m_{i 0}=\frac{1}{N} \sum_{j=1}^{N} \varphi_{i j}
$$

Fig. 5

Convergence rate and number of vacant data

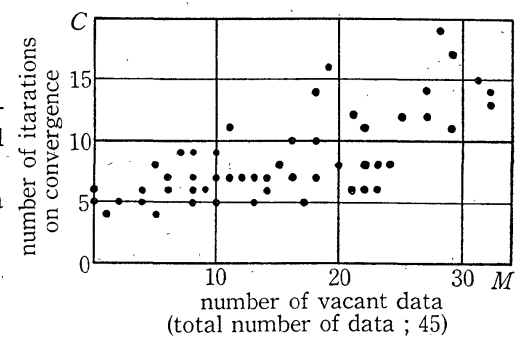

てれは，原点を通る直線による $f(m)$ の近似を最小 2 乗法の意味で最適に行ったものになるが(0)，いわゆ る一対比較法が与える解に相当するむのである(1),5).6) また，最初 $\varphi_{i j}$ をを作るときの $m_{i}$ を $m_{i}$ * とすると， $f(m)$ が単調増加関数であることから次式がいえる が,

$$
m_{i} *>m_{j} * \longrightarrow m_{i 0}>m_{j 0}
$$

これは (9)式を用いれば $m_{i}$ に関する順位は初期值の 段階ですでに整えられているととを意味する10). した がって，その分 $m_{i}$ の修正を行う計算回数が節約で き，実際他の初期值の与え方をすると収束に十数回の 計算回数を必要とする (Fig. 3 の結果はその一例で ある）むのが，（9)式で初期值を与えると数回の計算 回数で $S=0$ に収束することが確められている。乙 れは Fig. 3 の結果に対応させていえば計算回数 10 前後から計算を始めることに相当する。

（iii）不完備データの場合

すでに指摘されているように，一対比較法の最大の 難点は比較判断を対象のあらゆる組合せの対に対して 行わねばならない点にあり, 数の困難を伴っているこ とである ${ }^{1)}$. この点比較判断の個数を減らしたいが, 本アルゴリズムにおいては比較判断の結果が 1 部欠除 している不完備なデータに対してもまったく同一の手 順を適用するととができ, 存在するデータのみを用い て $m_{i}$ を求めることが可能である．ただしての場合の 初期值は，不完備データに対して（9)式を拡張した Gulliksen の方法 ${ }^{11)}$ にる結果を利用した. なお除く データの個数やどの $\varphi_{i j}$ を除くかの選択は一様乱数 を2 值化する方法を利用してランダムに行った.

Fig. 5 は除かれたデータの個数 $M$ と収束するに 必要とした計算回数 $C$ との関係を示したすのである. Fig. 5 を見ると，データの数が減少したため $m_{i}$ 間 の全体的調整が容易になりCが減少する側面と初期值 設定が乱されることによりCが増加する側面の相反す る両面が複雑に現れている.

Fig. 6 は， $S=0$ となったときの $m_{i}$ の值 $\bar{m}_{i}$ に 関し，その再現性の良さを次式で評価し， $M$ との関 


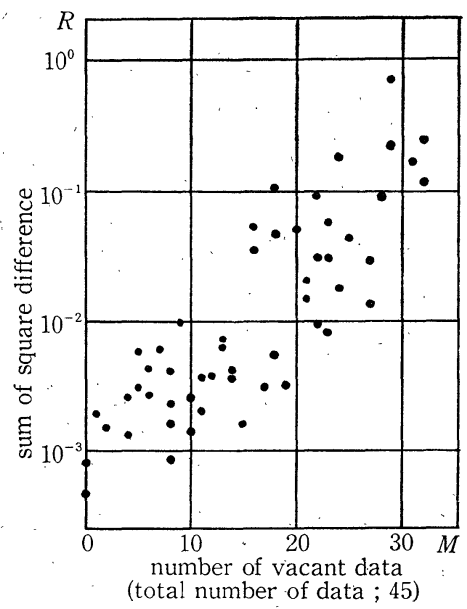

Fig. 6

Goodness of fit to original scale and number of vacant data

係を示したあのである

$$
R=\sum_{i=1}^{N}\left(\bar{m}_{i}-m_{i}^{*}\right)^{2}
$$

$M$ が増すにつれ $R$ の最大值つまり最悪のときの $m_{i}$ の再現性が悪くなることがわかるが， $M$ が大き いからといって必ずしも $m_{i}$ の再現性の質が悪くなる とは限らない.

なお収束の様子に特別な差異は現れなかった。

\section{2 帯関数モデルの幅がある場合}

まず幅のある帯関数モデルに対応した人工データを 作るため先に利用した $\varphi_{i ;}$ 亿乱数を加える手法をと った. 乱数としては平均值零の正規乱数, 一様乱数, 3 值乱数を用い，その分散の大きさを適当に変えた. 前節に述べたアルゴリズムに従い計算を行ったが， ここでは完備なデータに対する結果のみを示す。なお 計算にあたり不感帯の幅 $と$ は最初零とし 0.02 ピッチ で増加させ最終段階に近い所ではそのピッチを 0.01 に変更する方法をとっている...収束に必要をした計算 回数は加えた乱数の大きさのレベルにより異なってい るが, 一つの
Fig. 7

Width of dead zone and size of added random numbers

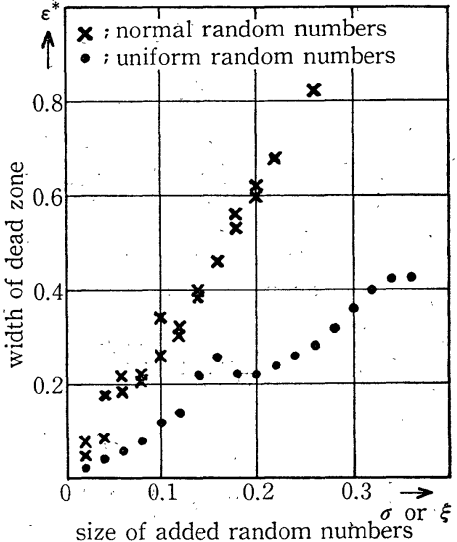

満定のいく結果が得られている.

Fig. 7 .は加えられた乱数が正規乱数 $N\left(0, \sigma^{2}\right)$ また は一様乱数 $U(-\xi, \xi)$ の場合, $S=0$ 亿達したときの $\varepsilon$ の大きさ $\varepsilon^{*}$ と $\sigma$ また $\xi$ と関係を図示したも のである。

Fig. 7 に見られるとおり $\varepsilon^{*}$ は加えられた乱数の大 きさにほぼ比例して増加している。. 本来不感帯幅は, 近接する $\varphi_{i j}$ に乱数が加わったため相互の正しい順 位が逆転しているととを考慮しようとするむので， $\varepsilon^{*}$ は逆転を生じている $\varphi_{i j}$ 間の差の絶対值に関する最 大值に一致するはずである（実際は $\varepsilon$ を増加させるピ ッチの大きさにより若干大きくなりうる). この点を

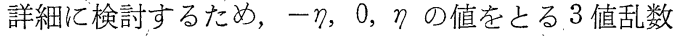
を用いた実験を行った．乙の場合 $\varepsilon^{*}$ の最大值が $2 \eta$ の值に近い值をとるかどうかで前述の考え方の正しさ が確められるが，結果は Table 2 亿示すとおりであ り，その考え方が正しいととがわかる．なお Table 2

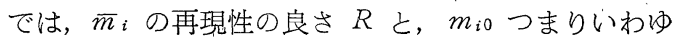
る一対比較法が与える解につ心て同様の評価を行った あの,すなわち

Table 2 Width of dead zone and goodness of fit to original scale with adding trinary random numbers

\begin{tabular}{|c|c|c|c|c|c|c|c|c|c|c|c|c|}
\hline & \multicolumn{2}{|c|}{$\eta=0.1$} & & & \multicolumn{4}{|c|}{$\eta=0.3$} & \multicolumn{4}{|c|}{$\eta=0.5$} \\
\hline$\varepsilon^{*}$ & \multicolumn{2}{|c|}{$R_{0}$} & \multicolumn{2}{|c|}{$R$} & $\varepsilon^{*}$ & \multicolumn{2}{|c|}{$R_{0}$} & $R$ & $\varepsilon^{*}$ & \multicolumn{2}{|c|}{$R_{0}$} & $R$ \\
\hline 0.20 & \multicolumn{2}{|c|}{$1.77 \times 10^{-3}$} & \multicolumn{2}{|c|}{$4.63 \times 10^{-4}$} & 0.52 & \multicolumn{2}{|c|}{$2.20 \times 10^{-3}$} & $1.19 \times 10^{-3}$ & 0.92 & \multicolumn{2}{|c|}{$2.90 \times 10^{-3}$} & $1.52 \times 10^{-3}$ \\
\hline 0.18 & 1.58 & $\prime \prime$ & 6.38 & $\prime \prime$ & 0.52 & 1.50 & $\dddot{\prime \prime}$ & 1.19 " & 0.92 & 1.56 & $\prime \prime$ & $1.38 \quad$ " \\
\hline 0.12 & 1.49 & "I & 2.98 & " & 0.52 & 1.27 & " & $3.85 \times 10^{-4}$ & 0.92 & 1.22 & " & 1.21 \\
\hline 0.20 & 1.61 & "' & 3.85 & " & 0.48 & 1.74 & " & $1.11 \times 10^{-3}$ & 0.90 & 2.16 & " & 2.52 \\
\hline 0.20 & 1.95 & I" & 5.58 & " & 0.56 & 2.85 & " & 1.86 & 0.96 & 4.19 & " & .4 .48 \\
\hline 0.20 & 1.82 & "I & 2.99 & " & 0.50 & 2.20 & " & $7.62 \times 10^{-4}$ & 0.90 & 2.67 & II. & $6.52 \times 10^{-4}$ \\
\hline 0.12 & 1.75 & " & 3.72 & $\prime \prime$ & 0.58 & 2.04 & $"$ & 9.56 & 0.88 & 2.42 & " & $2.27 \times 10^{-3}$ \\
\hline 0.16 & 1.50 & II. & 4.68 & " & 0.36 & 1.59 & " & $1.05 \times 10^{-3}$ & 0.62 & 2.20 & & 1.87 \\
\hline 0.20 & 1.64 & "I & 3.79 & "' & 0.58 & 1.70 & " & $9.30 \times 10^{-4}$ & & & & \\
\hline
\end{tabular}




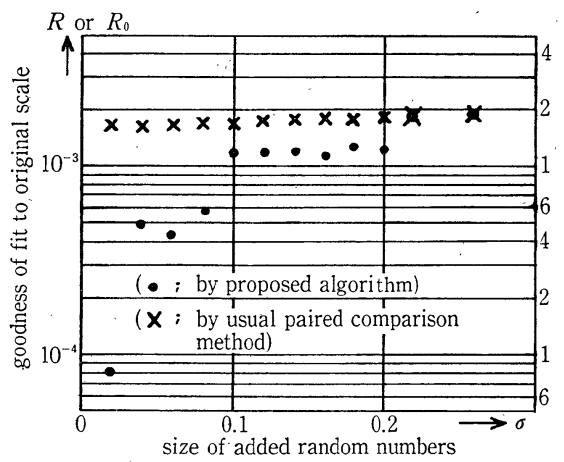

Fig. 8 Comparison of goodness of fit to original scale between proposed algorism and usual paired comparison method

$$
R_{0}=\sum_{i=1}^{N}\left(m_{i 0}-m_{i}{ }^{*}\right)^{2}
$$

が比較して示されている. そのような比較を正規乱数 を加えた場合について示したものが Fig. 8 である.

加わる乱数の大きさが大きくなると, $f(m)$ の関数 形に存在する非直線性が判断のあいまいさやばらつき の中に埋むれてしまい両者の区別がしにくくなるため 本アルゴリズムによる結果むいわゆる一対比較法の結 果と同程度の質をもった解を与えるようになる傾向が うかがわれる，したがって本アルゴリズムが最も効果 を発揮するのはあいまいさやばらつきが存在しかつそ の大きさに比して非直線性が大きく現れるような状況 であると考える。

\section{5. 重さの比較とアルゴリズムの実効性の検証}

本節では，本アルゴリズムのあつ実用上の効用を実 際的に検証するため，重さの主観的比較 (一対比較)
から得られたデータに提案したアルゴリズムを適用 し，どの程度正しく質量が再現できるかを考察した。

まず直径約 $31 \mathrm{~mm}$ ，高さ約 $53 \mathrm{~mm}$ のプラスチック 製不透明円筒を用意し，その中に鉄板およびアルミニ ウム板を入れ，直示天科を用いて $10 \mathrm{mg}$ の単位まで 質量を調整した 14 個の試料 $x_{1}, x_{2}, \cdots, x_{14}$ を作った (各試料の質量を Table 3 の左欄に示した).

つぎに被験者に対しランダムな対呈示を行いどちら が重いかを判断させた'(両手を用いる主観的比較). 被験者数は 8 名で, それぞれ 5 回の反復実験を行った ため，一つの対につき 40 回の比較を繰返したことに なる. 結果の集計を Table 3 に示すが, 数值は $x_{i}$ に 対し $x_{j}$ がより重いと判断された頻度を百分率で表し たものである ${ }^{12)}$ ，対角線の所は $50 \%$ とみなし，また 対角線に対し対称の位置にある要素はその和が $100 \%$ の関係にあるため左下半分の数值は省略してある.

このような結果を帯関数モデルに対応したデータと 見なせば，Fig.9 のような幅と非直線性を有する一 つの帯関数が得られる.

このデータに対し, いくつかの数值処理法を適用し て $m_{i}$ を求め, 試料の質量に関する平均值と分散に 合せて質量值に読み換えた結果を比較したものが

Table 4 である. Table 4 に执いて，(A) は Table 3 に関して右上方の余白を $100 \%$ と見なして完備させ たデータにつき不感帯幅を考慮するアルゴリズムを適 用しだすので， $\varepsilon^{*}=8 \%$ のとき $S=0$ に収束した.

（B）は完備なデータにつき，不感带の考え方を用いな いで $S$ が最小となったときの $m_{i}$ から質量を再現させ た場合である.（C）は（B）と同様であるがデータは Table 3 の不完備な数值のみを利用した場合である.

Table 3 Frequency on subjective comparison of weights

\begin{tabular}{|c|c|c|c|c|c|c|c|c|c|c|c|c|c|c|c|c|}
\hline \multirow[b]{2}{*}{ mass $\mathrm{g}$} & \multirow[b]{2}{*}{$i$} & \multicolumn{15}{|c|}{ frequency \% } \\
\hline & & $j$ & $X_{1}$ & $X_{2}$ & $X_{3}$ & $X_{4}$ & $X_{5}$ & $X_{6}$ & $X_{7}$ & $X_{8}$ & $X_{9}$ & $X_{10}$ & $X_{11}$ & $X_{12}$ & $X_{13}$ & $X_{14}$ \\
\hline 90.00 & $X_{1}$ & & , & 57.5 & 70.0 & 75.0 & 100 & & & & & & & & & \\
\hline 91.00 & $X_{2}$ & & & & 62.5 & 67.0 & 97.5 & 100 & & & & & & & & \\
\hline 92.00 & $X_{3}$ & & & & & 57.5 & 90.0 & 97.5 & 100 & & & & & & & \\
\hline 93.00 & $X_{4}$ & & & & & & 85.0 & 97.5 & 100 & & & & & & & \\
\hline 96.00 & $X_{5}$ & & $\therefore$ & & & & 3 & 67.5 & 95.0 & 100 & & & & & & \\
\hline 98.00 & $X_{6}$ & & & & & & & & 75.0 & 85.0 & 97.5 & 100 & & & & \\
\hline 100.00 & $X_{7}$ & & & & & & & & & 67.5 & 75.0 & 77.5 & 80.0 & 95.0 & 100 & \\
\hline 101.00 & $X_{8}$ & & & & & & & & & & 65.0 & 72.5 & 77.5 & 90.0 & 100 & \\
\hline 102.00 & $X_{9}$ & & & & & & & & & & & 65.0 & 72.5 & 80.0 & 90.0 & 97.5 \\
\hline 103.00 & $X_{10}$ & & & & & & & & & & & & 67.5 & 72.5 & 87.5 & 95.0 \\
\hline 104.00 & $X_{11}$ & & & & & & & & & & & & & 62.5 & 82.5 & 92.5 \\
\hline 105.00 & $X_{12}$ & & & & & & & & & & & & & & 65.5 & 92.5 \\
\hline 107.00 & $X_{13}$ & & & & & & & & & & & & & & & 72.5 \\
\hline 109.00 & $X_{14}$ & & & & & & & & & & & & & & & \\
\hline
\end{tabular}




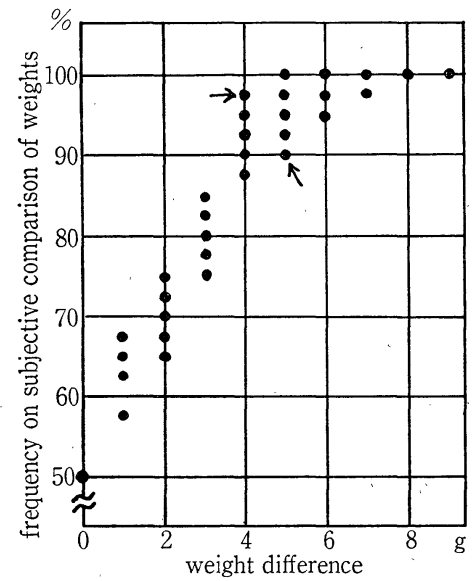

Fig. 9 Band function on subjective comparison of weights

(D) は完備なデータにつき $(9)$ 式から 質量を再現したあのである.（E)は完 備なデータにつき Thurstone のケー スVの方法55を適用した結果である. この場合データに $100 \%$ の数值が多数 あり，その処理が難しいため良い結果 が得られないが参考のため記載した。

Table 4 では実際の質量と再現された質量の差の 2 乗和が示されて抢り，それらを比較すると本アルゴリ ズムの有効さが理解できる。なお Fig. 9 の中でー印 で指示されている 2 点は，乙のデータの中で順位の逆 転をきたし最大の差を与える 2 点でその差は $7.5 \%$ で あるが，(A)の $\varepsilon^{*}=8 \%$ はこれとよく一致している.

\section{6. あとがき}

本研究では一対比較法に関し帯関数モデルを提案 し，そのようなデータから間隔尺度を構成するため不 感帯幅を考慮した非計量的アルゴリズムにつき考察し た.

人工データを用いてアルゴリズムのもつ主要な基本 的性格を検討すると共に, 重さの主観的比較実験に適 用しアルゴリズムの実用性を確めた。また従来の一対 比較法の処理結果と比較し, より質の良い結果を与え る可能性のある効果的な手法であるととが判明した.

本方法が最む勃果を発揮するのは, データの欠除, ばらつきや非直線性が強く存在する状況之思われる が，今後さまざまの分野におけ、る実際的活用を考えて みたい.

なお，このようなアルゴリズムのもつ数理的性質の 解析や, Scheffé の方法に見られる順序効果, 組合せ 効果の分析への適用可能性などは残された今後の検討 課題である、また筆者らは本手法を非計量一対比較法 real weights

\begin{tabular}{|c|c|c|c|c|c|c|}
\hline \multirow{3}{*}{$\begin{array}{l}\text { real } \\
\text { weight } g\end{array}$} & \multicolumn{5}{|c|}{ reconstructed weight $\mathrm{g}$} & \multirow{3}{*}{ remark } \\
\hline & \multicolumn{3}{|c|}{ nonmetrical algorism } & \multicolumn{2}{|c|}{$\begin{array}{l}\text { usual paired } \\
\text { comparison } \\
\text { method }\end{array}$} & \\
\hline & (A) & (B) & (C) & (D) & (E) & \\
\hline 90.00 & 90.23 & 90.43 & 90.23 & 90.72 & 94.44 & \multirow{3}{*}{$\begin{array}{l}\text { (A); } \\
\text { complete data, } \\
\text { consider dead zone. }\end{array}$} \\
\hline 91.00 & 91.03 & 91.05 & 91.05 & 91.23 & 92.88 & \\
\hline 92.00 & 91.85 & 92.09 & 92.05 & 92.13 & 92.74 & \\
\hline 93.00 & 92.43 & 92.16 & 92.23 & 92.60 & 95.07 & \multirow{4}{*}{$\begin{array}{l}\text { (B); } \\
\text { complete data, } \\
\text { neglect dead zone. }\end{array}$} \\
\hline 96.00 & 96.03 & 95.78 & 95.96 & 95.61 & 101.76 & \\
\hline 98.00 & 97.79 & 97.78 & 97.80 & 97.09 & 98.33 & \\
\hline 100.00 & 100.48 & 100.03 & 100.11 & 99.75 & 93.89 & \\
\hline 101.00 & 101.32 & 101.19 & 101.38 & 100.88 & 96.19 & \multirow{7}{*}{$\begin{array}{l}\text { (C); } \\
\text { imcomplete data, } \\
\text { neglect dead zone. }\end{array}$} \\
\hline 102.00 & 102.30 & 102.47 & 102.58 & 102.21 & 97.98 & \\
\hline 103.00 & 103.16 & 103.40 & 103.22 & 103.15 & 97.96 & \\
\hline 104.00 & 104.05 & 103.91 & 104.31 & 104.20 & 102.80 & \\
\hline 105.00 & 105.02 & 105.04 & 104.84 & 105.49 & 108.87 & \\
\hline 107.00 & 106.74 & 106.75 & 106.64 & 107.21 & 106.07 & \\
\hline 109.00 & 108.63 & 108.66 & 108.58 & 108.73 & 112.25 & \\
\hline $\begin{array}{l}\text { sum of } \\
\text { square } \\
\text { difference }\end{array}$ & $\begin{array}{c}1.1020 \\
\varepsilon^{*}= \\
8.0 \%\end{array}$ & 1.6036 & 1.6614 & 2.2750 & 192.8 & $\begin{array}{l}\text { complete data, } \\
\text { Thurstone method } \\
\text { case V. }\end{array}$ \\
\hline
\end{tabular}

と名付けたいと考えている.

\section{参 考 文 献}

1) 日科技連官能検查委員会編：新版官能検查ハンドブッ ク，241/570，日科技連出版社（1973）

2) S.S. Stevens: On the Theory of Scales of Measurement, Science, 103, 670/680 (1946)

3）芝祐順：因子分析法, 東大出版会 (1972)

4) 北川敏男編: 多変量解析諭, 一共立出版 (1967)

5） J.P. ギルホード: 精神測定法(秋重義治監訳), 189/218 培風館 (1971)

6) H. Scheffé: An Analysis of Variance for Paired Comparisons, J. Am. Stat. Ass., 47, 381/400 (1952)

7) R. N. Shepard: Analysis of Proximities as a Technique for the Study of Information Processing in Man, Human Factors, 5-2, 33/48 (1963)

8) J.B. Kruskal: Multidimensional Scaling by Optimizing Goodness of Fit to a Nonmetric Hypothesis, Psychometrika, 29-1, 1/27 (1964)

9) J.B. Kruskal: Nonmetric Multidimensional ScalingA Numerical Method, Psychometrika, 29-2, 115/ 129 (1964)

10）小林彬：最小 2 乗法之順序関係，第 18 回自動制御連合 講演会前刷, 1124 (1970)

11) H. Gulliksen: A Least Squares Solution for Paired Comparison with Incomplete Data, Psychometrika 21, 125/134 (1956)

12) 諏訪部和之: 順序構造之計測, 東京工業大学制御工学科 修士論文 (1976)

13）芝田勉：一対比較法のための非計量的処理, 東京工業大 学制御工学科卒業論文 (1977)

14）小林彬, 芝田勉: 主観的比較計量々順位差を利用する非 計量尺度構成, 第 19 回自動制御連合講演会前刷, 4002 (1976)

15）小林彬：いくつかの順序則と判定関数のための帯関数モ デル, 第 14 回 SICE 学術講演会予稿集, 3514 (1975) 